\title{
Tensile strength of the posterior and anterior layer of the rectus abdominis muscle sheath in cadavers ${ }^{1}$
}

\author{
Tensão das bainhas anterior e posterior do músculo reto do abdome em cadáveres
}

\author{
Carlos Roberto Amorim², Fábio Xerfan Nahas ${ }^{3}$, Virgínio Cândido Tosta de Souza ${ }^{4}$, Pedro Bins Ely ${ }^{5}$, Romar Ângelo \\ Barbato Silveira $^{2}$, Neil Ferreira Novo ${ }^{6}$, Lydia Masako Ferreira ${ }^{7}$
}

1. Research performed at Vale do Sapucaí University (UNIVÁS), Pouso Alegre (MG), Brazil.

2. Fellow Master degree, Postgraduate Program, Federal University of São Paulo (UNIFESP), Brazil.

3. Associate Professor, Division of Plastic Surgery, Department of Surgery, UNIFESP, Brazil.

4. Full Professor, Department of Colon and Rectum Surgery, UNIVÁS, Pouso Alegre (MG), Brazil.

5. PhD, Preceptor Plastic Surgery Unit Santa Casa Porto Alegre, Rio Grande do Sul, Brazil.

6. Full Professor, Bioestatistics of the University Santo Amaro (UNISA), São Paulo, Brazil.

7. Full Professor, Division of Plastic Surgery, Department of Surgery, UNIFESP, Brazil.

\begin{abstract}
Purpose:The aim of the present study was to assess, in cadavers, the resistance to medial traction of the posterior and anterior layer of the rectus abdominis muscle sheath. Methods: An anatomical, prospective, self-controlled study was carried out in 20 male cadavers. An evaluation of the tension of the posterior and anterior layers of the rectus abdominis muscle sheath was performed following anatomical dissection of these structures. The traction necessary to advance the tissue ten millimeters was assessed using an analogic dynamometer. Results There was no significant statistical difference between the necessary traction at various levels of the anterior and posterior layers of the rectus sheath. However, medial advancement of the anterior layer of the rectus sheath required more traction strength than did advancement of the posterior layer to the midline. Conclusion: There is no difference in the tensile strength in the various levels of the anterior and posterior layers of the rectus sheath; however, medial advancement of the the anterior layer required more traction strength.
\end{abstract}

Key words: Abdominal muscles. Tensile strength. Rectus abdominis. Cadáver.

\section{RESUMO}

Objetivo: Comparar a resistência à tração medial das lâminas posterior e anterior da bainha do músculo reto do abdome em diferentes níveis supra e infra-umbilicais em cadáveres. Métodos: Vinte cadáveres adultos foram submetidos à dissecção da parede abdominal anterior. Foram feitas alças com fio de náilon no plano aponeurótico em oito pontos diferentes na lâmina anterior e na lâmina posterior da bainha do músculo reto do abdome, sendo quatro destes pontos supra-umbilicais e quatro infra-umbilicais. Com o uso de um dinamômetro analógico, foi verificada a força necessária para o avanço medial de dez milímetros destes dezesseis pontos. Resultados: Não foram encontradas diferenças significantes de medidas da resistência à tração entre os diferentes níveis da aponeurose anterior e posterior, mas quando se comparou as medidas obtidas na aponeurose anterior às obtidas na posterior verificou-se que a aponeurose anterior necessitou de maior força de tração para o avanço medial. Conclusão: Não há diferença de tensão ao longo da aponeurose anterior e posterior. A aponeurose anterior é mais resistente à tração medial quando comparada à posterior.

Descritores: Músculos Abdominais. Resistência à Tração. Reto do Abdome. Cadáver. 


\section{Introduction}

The abdominal wall plays an important role in numerous physiological activities, including voluntary movement, the vomit mechanism, childbirth, micturition, and evacuation ${ }^{1}$. Medial laparotomy provides easy and rapid access to the abdominopelvic cavity with ample visceral exposition, allowing access to all major abdominal structures, including the retroperitonium. This kind of incision promotes minimal blood loss due to the nonvascular nature of the linea alba. For these reasons, the medial incision is the approach preferred by a majority of surgeons, particularly for urgent procedures and exploratory laparotomy ${ }^{2}$. An important detail to the procedure, however, is the reconstruction of the abdominal wall, which must ultimately exhibit low tension and be carried out by suturing viable structures using strong material ${ }^{3}$. A primary cause for the increased incidence of hernias following medial laparotomy is excessive tension in the suture line ${ }^{4,5}$. This tension generates ischaemia in the muscle-aponeurotic plan and, consequently, dehiscence and abdominal injury. The aim of the present study was to evaluate, using cadavers, the medial tensile strength of the posterior and anterior layers of the rectus abdominis muscle sheath across four levels, two below and two above the umbilicus.

\section{Methods}

Twenty adult cadavers were dissected. The cadavers were fresh (not fixed), and were obtained at a maximum post-mortem interval of 24 hours. The cadavers were stored at ambient temperature. The sex or race did not have any election in relation. With the cadaver placed in the supine position (horizontal dorsal decubitus), a xifopubic incision including the superficial fascia was carried out using a scalpel blade number 22 until the linea alba and surrounding umbilicus were exposed. After dissection between the superficial fascia and the anterior layer of the rectus sheath, the linea alba was delimited and excised, creating a defect in the muscle-aponeurotic plan. Access to the posterior layer of the abdominal rectus muscle was therefore established. Dissection of the posterior face of the rectum muscle was carried out through its posterior layer. The sixteen points points for our study of muscle traction were demarcated: eight points were in the anterior layer and eight points were in the posterior layer (Figure 1). Of the eight points in each layer, four were positioned superior to the umbilicus (three and six $\mathrm{cm}$ above the umbilicus) and four were inferior (two and four centimeters below the umbilicus). The symmetrical points were equidistant in relation to the medial edge of the aponeurosis and this distance was of ten millimeters for each point. In each one of the sixteen points, was performed a handle, with diameter of five millimeters ( $\mathrm{mm}$ ) through a point in " $\mathrm{X}$ " with nylon wire number 00, involving only the aponeurotic plan. With the purpose to measure the necessary traction for the advance of ten millimeters in each point in the direction of the median line, an analogical dynamometer was used (hardwired to the handle, located in straight angle in relation to the median line. It was used an analogical paquimeter fixed in a connecting rod to measure the advance of ten millimeters (Figure 2).

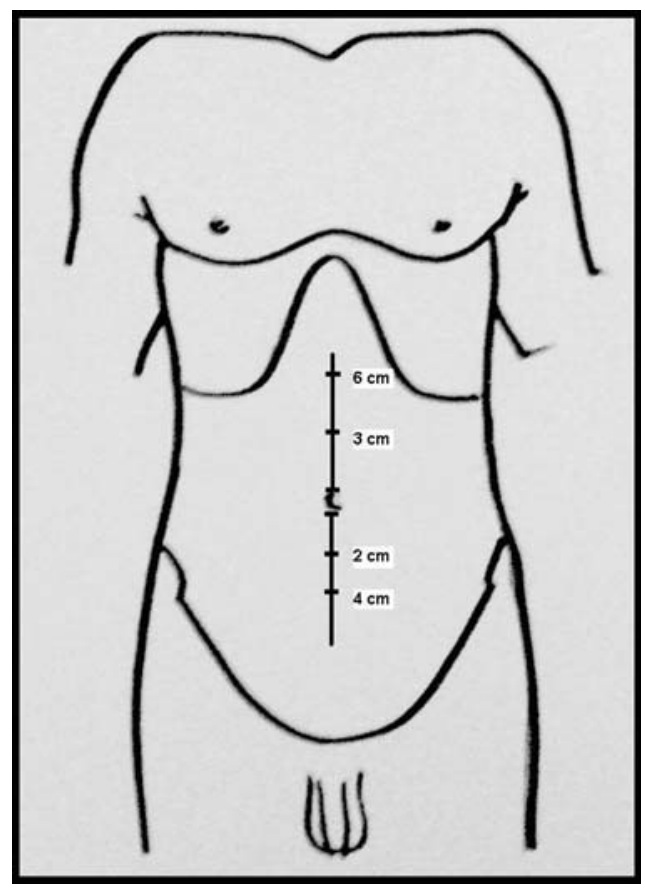

FIGURE 1 - Project showing studied heights

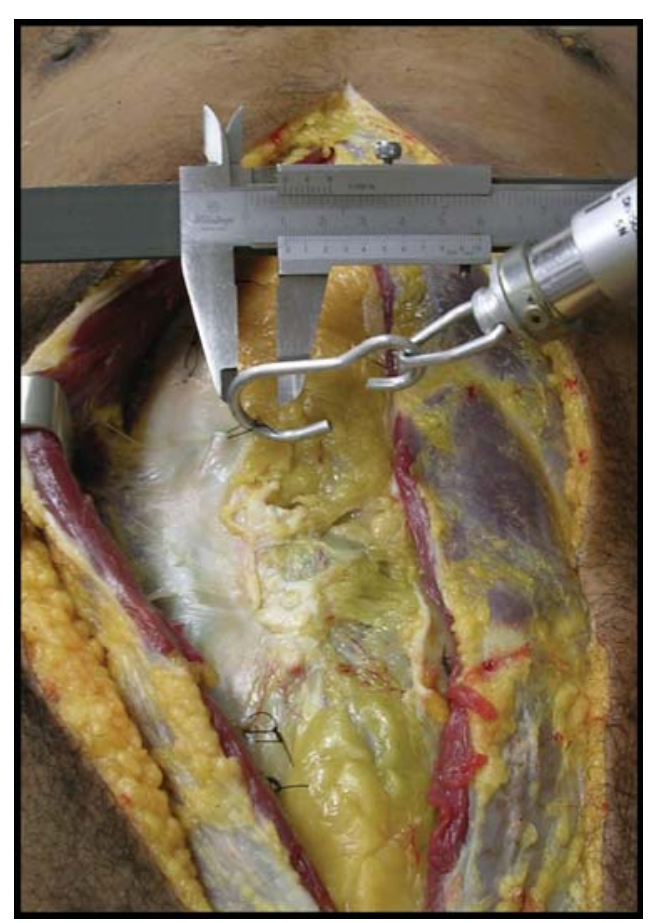

FIGURE 2 - Photograph illustrating the use of the dynamometer and the analogical paquimeter 
The dynamometer was pulled perpendicularly to the median line for the researcher, while another observer verified the advance of ten millimeters of the anterior and posterior layers of the rectum sheath. All measures with the dynamometer had been repeated by another researcher. When it had discrepancy, the accepted value was the average between the two measures. After each session of study, the dynamometer was revised and calibrated. After the collection of the information, with the objective to make possible the comparison of the muscle-aponeurotic resistance in the studied points, each gotten measure was related at a distance advanced of ten millimeters. The traction coefficient was then used, calculated by means of the following formula:

$$
\mathrm{Ct}=\frac{\mathbf{T}}{\mathbf{d}}
$$

$\mathrm{Ct}=$ Coefficient of traction $(\mathrm{Kgf} / \mathrm{cm})$; $\mathrm{T}=$ traction $(\mathrm{Kgf})$, measure with the dynamometer, in each definitive point; $d$ = distance $(\mathrm{cm})$ of the aponeurotic point until the median line. Because the distance that the layers of the rectal sheath were advanced remained constant $(10 \mathrm{~mm})$, the traction coefficient reflects the proper value of the traction in $\mathrm{Kgf} / \mathrm{cm}$.

The means between the corresponding points on the right and left sides were calculated. These points are described in Chart 1.

\section{CHART 1}

Level I

Level II

Level III

Level IV
$6 \mathrm{~cm}$ upper the umbilicus

$3 \mathrm{~cm}$ upper the umbilicus

$2 \mathrm{~cm}$ lower the umbilicus

$4 \mathrm{~cm}$ lower the umbilicus

For data analysis we used the following tests: 1) Wilcoxon's Test $^{7}$ to compare the anterior and posterior measures at each level. 2) Friedman,s Analysis of Variance $^{7}$ to separately compare the four levels in the anterior points with the four posterior levels. Results were considered statistically significant when $\mathrm{P}<0.05$.

TABLE 1 - Coefficients of traction of the anterior and posterior layers of the aponeurosis of the rectus muscle in different levels in cadavers in $\mathrm{Kgf} / \mathrm{cm}$

\begin{tabular}{|c|c|c|c|c|c|c|c|c|}
\hline & \multicolumn{2}{|c|}{ Level I } & \multicolumn{2}{|c|}{ Level II } & \multicolumn{2}{|c|}{ Level III } & \multicolumn{2}{|c|}{ Level IV } \\
\hline & Anterior & Posterior & Anterior & Posterior & Anterior & Posterior & Anterior & Posterior \\
\hline & 3.25 & 3.50 & 3.75 & 3.75 & 3.75 & 3.50 & 4.25 & 3.50 \\
\hline & 2.50 & 2.50 & 2.75 & 2.50 & 3.50 & 2.00 & 2.75 & 3.00 \\
\hline & 3.00 & 2.00 & 3.00 & 3.00 & 3.50 & 2.00 & 3.50 & 1.50 \\
\hline & 3.50 & 2.00 & 3.50 & 2.25 & 3.50 & 2.25 & 4.00 & 2.75 \\
\hline & 2.50 & 2.00 & 2.50 & 2.50 & 3.50 & 2.75 & 3.50 & 3.50 \\
\hline & 2.00 & 1.50 & 2.00 & 1.50 & 2.25 & 2.00 & 2.50 & 1.75 \\
\hline & 2.50 & 2.00 & 2.50 & 2.00 & 3.25 & 2.00 & 3.25 & 2.00 \\
\hline & 3.50 & 2.00 & 3.50 & 2.00 & 3.50 & 2.00 & 3.75 & 2.00 \\
\hline & 2.25 & 2.25 & 2.25 & 2.25 & 2.25 & 3.00 & 2.50 & 3.25 \\
\hline & 3.00 & 4.00 & 3.00 & 4.00 & 3.00 & 4.00 & 3.00 & 4.00 \\
\hline & 2.75 & 3.25 & 2.50 & 2.75 & 2.25 & 2.25 & 2.25 & 2.25 \\
\hline & 2.25 & 2.00 & 2.25 & 1.75 & 1.75 & 1.75 & 2.00 & 1.75 \\
\hline & 2.50 & 2.50 & 2.25 & 2.25 & 2.75 & 2.00 & 3.25 & 2.25 \\
\hline & 3.50 & 2.75 & 3.50 & 2.25 & 3.50 & 2.25 & 3.50 & 2.25 \\
\hline & 3.50 & 2.75 & 5.00 & 3.25 & 3.25 & 3.25 & 3.50 & 3.00 \\
\hline & 2.50 & 2.75 & 2.25 & 2.25 & 2.75 & 2.25 & 2.75 & 2.50 \\
\hline & 3.50 & 3.25 & 3.50 & 3.25 & 3.50 & 3.50 & 4.00 & 3.50 \\
\hline & 3.00 & 2.50 & 2.50 & 2.25 & 2.75 & 2.50 & 2.25 & 2.50 \\
\hline & 2.50 & 2.00 & 2.75 & 1.75 & 2.00 & 2.00 & 2.00 & 2.00 \\
\hline & 4.00 & 3.25 & 4.00 & 3.00 & 3.50 & 2.75 & 3.00 & 2.75 \\
\hline 0 & 2,90 & 2.54 & 2.96 & 2.56 & 3.00 & 2.50 & 3.08 & 2.60 \\
\hline $\mathrm{Mi}$ & 2,88 & 2.50 & 2.75 & 2.25 & 3.25 & 2.25 & 3.13 & 2.50 \\
\hline
\end{tabular}

\section{Results}

Statistical analysis with Friedman,s Analysis of Variance comparing the values obtained in the anterior layer and the posterior layer of rectus muscle sheath. (Anterior x Posterior)

$$
\frac{\text { Anterior }}{\mathrm{x}^{2} \mathrm{cal}=4,73(\mathrm{NS})} \quad \frac{\text { Posterior }}{\mathrm{x}^{2} \mathrm{cal}=1,41(\mathrm{NS})}
$$

Statistical analysis with Wilcoxon's test comparing the values obtained over the various levels.

(Level I x Level II x Level III x Level IV)

$\begin{array}{cc}\text { Level I } & \text { Level II } \\ \mathrm{Z} \text { calc }=2,34^{*} & \text { T calc }=11,5 \\ \mathrm{P}<0,001 & \text { ant }>\text { post } \\ \text { ant }>\text { post } & \end{array}$




\begin{tabular}{cc} 
Level III & Level IV \\
\cline { 3 - 3 } Z calc $=2,53^{*}$ & $\mathrm{Z}$ calc $=2,37^{*}$ \\
$\mathrm{p}<0,001$ & $\mathrm{p}<0,001$ \\
ant $>$ post & ant $>$ post
\end{tabular}

Statistical analysis with Wilcoxon's test comparing the values obtained over the various levels.

(Level I x Level II x Level III x Level IV)

A statistical analysis of the data demonstrated that, within a single aponeurosis, there were no differences between the different levels of the anterior or posterior layers of the rectus muscle. However, the values obtained in the anterior layer were significantly greater than those obtained from the posterior layer of the aponeurosis.

\section{Discussion}

Incisions in and subsequent closures of the anterior abdominal wall, particularly along the median line, are among the most frequent surgical approaches for abdominal surgery. The closure of the abdominal wall must be executed carefully to diminish postoperative defects in the anterior abdominal wall that can result from excessive tension in the sutures. An excess of tension in the suture line, generating ischaemia and tecidual necrosis, has been associated with an increased incidence of abdominal hernias. To investigate the necessary tension required to move abdominal muscles a fixed distance relative to the median abdominal line, we used fresh cadavers, obtained less than 24 hours post-mortem. However, during this period, cadavers can suffer under the influence of abiotic factors, including an abolition of immediate muscular strength, dehydration and gradual weight loss, and varied degrees of cadaver rigidity ${ }^{8}$. Van Geffen et. al. ${ }^{9}$ compared two groups of cadavers: fresh and those submitted to low temperatures (not fixed). These authors did not observe any differences in the mobilization of the abdominal walls due to rigor mortis. In living bodies, the tension in the abdominal wall is caused by the centrifugal force of the abdominal contents and by the contraction of the abdominal muscles with a vector of lateral force (generated by the external oblique, internal oblique and transversus muscles of the abdominal wall $)^{10}$. Moreover, following the surgical closure of the abdominal wall, bowel edema, gaseous distension, and an increase in post-operative ileum content increase the intra-abdominal pressure to varying degrees 11,12. There were excluded cadavers that presented with alterations in the abdominal wall or intraperitoneal changes that could restrict the muscle-aponeurotic components. The opening of the peritoneum was prevented in order to facilitate the measurements. Nahas and Ferreira ${ }^{4}$ developed an experimental model to study the tension of the abdominal wall using cadavers ${ }^{4}$. These authors were able to evaluate the resistance mechanics of the abdominal wall in human cadavers, without interference from the dynamic changes occurring in the core muscles of living tissue. The location of the four aponeurotic points allowed for a detailed evaluation of regions both above and below the umbilicus, as well as both the aponeurotic layers (anterior and posterior). The required tensions were surveyed with a dynamometer that measures the tension force generated by the displacement of a spring, generating results along a linear scale with divisions of 500gf. The traction of the dynamometer was perpendicular to the midline, tangential to the aponeurosis, and limited to $10 \mathrm{~mm}$, demarcated for one analogical paquimeter. This method has previously been used successfully in studies of abdominal wall mobility in cadavers $4,13,14,15,16$. To compare the results with those from other studies, the obtained values were calculated into a coefficient of traction that takes into account the distance covered for each point. Because this distance was fixed to $10 \mathrm{~mm}$, the actual value of the traction measured in Kgf corresponds to the value of the traction coefficient in Kgf/cm. The option for the fixed distance had it the fact of the handles breached when were tractioned until the middle line, during the pilot study. This was most likely due to lateral movement of the abdominal muscles following excision of the linea alba. The arithmetic means between the corresponding points on each side of the body were calculated to generate representative values ${ }^{4,14,15,16}$. The regional coefficients of traction were highly variable between cadavers, and did not exhibit a normal distribution. For this reason, we employed statistics that evaluate abnormally distributed populations. Paired regional coefficients for traction measurements were compared using Friedman variance's analysis. The paired regional coefficients of traction for the anterior and posterior layers, over all levels above and below the umbilicus were compared using Wilcoxon's test. We found that, across all levels of the abdominal wall, the anterior layer was more resistant to medial traction, and required a larger traction force for medial retraction. However, at $3 \mathrm{~cm}$ above the umbilicus, there was no significant difference between the anterior and posterior layers. These findings are consistent with results from previous studies ${ }^{4,14,15,16}$. However these studies evaluated only one point above and below the umbilicus, but took measurements following various types of muscle-aponeurotic manipulation. This difference can be explained by the disposal and quantification of colagem fibres of the rectus muscle are different in the two layers (anterior and posterior) ${ }^{17}$. When we evaluated the points across the upper and lower umbilicus regions, we found no differences in either the anterior or posterior layers. These findings were consistent with previous work conducted by Nahas et al. ${ }^{13}$ When this study was conceived, it was thought that it would have a bigger tension exerted for the upper levels when comparative to the lower ones. Importantly, in the anterior layer, the composition of the layers in the longitudinal direction is gradually modified by the fibers of the aponeuroses of the oblique internal and transverse abdominal muscles, resulting in a thinning of 
the anterior layer at the level of the anterior superior iliac spine to the pubic symphysis, and forming the hooped line ${ }^{18}$. For this reason many surgeons prefer closure of the anterior layer for reconstructing defects in the abdominal wall.

\section{Conclusion}

There is no difference in the medial tensile strenght in the levels studied in the anterior and the posterior layer of the rectus abdominis muscle sheath. In the anterior layer, the necessary force for the medial advance is significantly bigger when is compared with the posterior layer of the rectus mucle sheath.

\section{References}

1. Koshima I, Nanba Y, Tutsui T, Takahashi Y, Itoh S, Kobayashi R. Dynamic Reconstruction of large abdominal defects using a free rectus femoris musculocutaneous flap with normal motor function. Ann Plast Surg. 2003;50(4):420-4.

2. Burger JW, Van't Riet M, Jeekel J. Abdominal incisions: techniques and postoperative complications. Scand J Surg. 2002;91(4):315-21.

3. Larson GM. Ventral hernia repair by the laparoscopic approach. Surg Clin North Am. 2000;80:1329-40.

4. Nahas FX, Ferreira LM. Modelo experimental de cadáver para estudo de tensão de parede abdominal. Acta Cir Bras. 2003;18:37-45. Edição Especial. Disponível em URL: http://www.scielo.br/acb.

5. Cohen M, Morales R, Fildes J, Barrett J. Staged reconstruction after gunshot wounds to the abdômen. Plast Reconstr Surg. 2001;108:83-92.

6. Mäkelä JT, Kiviniemi H, Juvonen T, Laitinen S. Factors influencing wound dehiscence after midline laparotomy. Am J Surg. 1995;170:387-90.

7. Siegel S, Castelani JR. Estatística não paramétrica para ciências do comportamento. 2ed. Porto Alegre: Artmed; 2006.

8. França GV. Medicina legal. Rio de Janeiro: Guanabara Koogan; 2004.
9. Van Geffen HJAA, Simmermacher RKJ, Bosscha K, Van der Werkwn C, Hillen B. Anatomical considerations for surgery of the anterolateral abdominal wall. Hernia. 2004;8:93-7.

10. Levine JP, Karp S. Restoration of abdominal wall integrity as a salvage procedure in difficult recurrent abdominal wall hernias using a method of wide myofascial release. Plast Reconstr Surg. 2001;707-16.

11. Ramirez OM, Rua E, Dellon AL. "Components separation” method for closure of abdominal-wall defects: an anatomic and clinical study. Plast Reconstr Surg. 1990;86:519-26.

12. Fabian TC, Croce MA, Pritchard FE, Minard G, Hickerson WL, Howell RL, Schurr MJ, Kudsk KA. Planned ventral hernia: staged management for acute abdominal wall defects. Ann Surg. 1994;219:643-53.

13. Nahas FX, Ishida J, Gemperli RF, Ferreira MC. Abdominal wall closure after selective aponeurotic incision and undermining. Ann Plast Surg. 1998;41:606-17.

14. Barbosa MV. Resistência à tração dos components músculo-aponeuróticos da parede abdominal em cadáveres [Tese - Mestrado]. Universidade Federal de São Paulo - Escola Paulista de Medicina; 2005.

15. Barbosa MV. Resistência à tração dos components músculo-aponeuróticos da parede abdominal, em cadáveres, com e sem incisão da aponeurose do músculo oblíquo externo na linha semilunar. [Tese Doutorado]. Universidade Federal de São Paulo Escola Paulista de Medicina; 2006.

16. Kimura AK. Tecido celular subcutâneo na resistência à tração dos componentes músculo-aponeuróticos da parede abdominal em cadáveres. [Tese - Mestrado]. Universidade Federal de São Paulo - Escola Paulista de Medicina; 2006.

17. Axer H, Keyserlingk DG, Prescher A. Collagen fibers in linea alba and rectus sheaths: variability and biomechanical aspects. J Surg Res. 2001;96:239-45.

18. Risk NN. A new description of the anterior abdominal wall in man and mammals. J Anat. 1980; 131:373-85.

\section{Correspondence:}

Carlos Roberto Amorim

Av. Cel. Alfredo Custódio de Paula, 685

37.550-000 Pouso Alegre - MG Brazil

Phone: (55 35)9984-6091 / 3423-5000

amorimcr@yahoo.com.br
Conflict of interest: none Financial source: none

Received: March 12, 2007 Review: May 15, 2007 Accepted: June 15, 2007

\section{How to cite this article}

Amorim CR, Nahas FX, Souza VCT, Ely PB, Silveira RAB, Novo NF, Ferreira LM. Tensile strength of the posterior and anterior layer of the rectus abdominis muscle sheath in cadavers. Acta Cir Bras. [serial on the Internet] 2007 JulyAug;22(4). Available from URL: http://www.scielo.br/acb 